\title{
The Role Of Prosecutors In Handling Eradication Of Corruption Crime
}

\author{
Agustinus Dian Leo Putra*) and Gunarto**) \\ *) Master of Law Program, Faculty of Law Universitas Islam Sultan Agung email \\ dianleoputra@gmail.com \\ $\left.{ }^{* *}\right)$ Faculty of Law Universitas Islam Sultan Agung
}

\begin{abstract}
The purpose of this study is to examine and analyze the role of the Prosecutor's Office in handling criminal acts of corruption judicially. In this paper the author uses a normative juridical method. Based on the research, it can be concluded that the duties and functions of the prosecutor as an investigator of criminal acts of corruption are in accordance with the provisions of Article 284 paragraph (2) of the Criminal Procedure Code, the Prosecutor is still authorized to carry out investigations of special crimes in this case corruption. Eradication of corruption is to rely on the consistent treatment of Law on the eradication of corruption. 20 of 2001 concerning amendments to Act No. 31 of 1999 concerning the eradication of corruption. The prosecutor as an investigator concurrently serves as a public prosecutor in handling corruption crimes. Exceptions based on Article 284 paragraph (2) of the Criminal Procedure Code. The Criminal Procedure Code has relinquished the investigative authority from the prosecutor's office, and has been fully assigned to the police
\end{abstract}

Keywords: Prosecutors; Eradication; Corruption Crimes.

\section{Introduction}

The territory of Indonesia is a Rechtstaat, meaning that all actions within the government, whether in administering government in the life of the state, as a nation or as a citizen, must all be based on the law without the slightest exception, because it is a consequence that must be carried out by the Indonesian Territory as an area covered by regulations. ${ }^{1}$ The law stipulates what must be done and or what can be done and what is prohibited. The legal targets to be addressed are not only people who are actually acting against the law, but legal actions that may occur, and to state equipment to act according to the law. The working system of such a law is a form of law enforcement. ${ }^{2}$ One of the crimes that can be said to be quite phenomenal is the problem of corruption.

Corruption in Indonesia is widespread in society. Its development continues to increase from year to year. The increase in uncontrolled corruption will bring disaster, not only to the life of the national economy but also to the life of the nation and state in general. ${ }^{3}$ Corruption is a violation of social rights and economic rights of the

\footnotetext{
${ }^{1}$ Saipuddin Zahri, 2016, Problema Penyidikan Tindak Pidana Korupsi, Palembang: Tunas Gemilang Press, p. 1.

2 Evi Hartanti, 2005, Tindak Pidana Korupsi, Sinar Grafika, Jakarta, p.1

3 Muhamad Riyadi Putra and Gunarto, Analysis Of Handling Practices On Corruption Crime By Police (Case Study In Special Criminal Investigation Police Directorate Of Central Java), Jurnal Daulat Hukum Volume 2 Issue 2, June 2019, url: http://jurnal.unissula.ac.id/index.php/RH/article/view/5425/3346
} 
community. Corruption has become an extraordinary crime. Likewise, eradication efforts can no longer be carried out in an ordinary way, but are required in an extraordinary way. Furthermore, it is proven that there is a link between corruption and other forms of crime, especially organized crime (terrorism, trafficking in persons, smuggling of illegal migrants and others) and economic crimes (money laundering). So that the crime Corruption is a crime that is very detrimental to the state. ${ }^{4}$

In Indonesia, there are law enforcers, one of which is the Prosecutor's Office. The formation of the Prosecutor is based on Act No. 16 of 2004 concerning the Prosecutor's Office which in the considering section explains Indonesia's national goals are law enforcement and justice as well as one of the bodies whose functions are related to the composition of the Prosecutor's Office according to Act No. 16 of 2004 concerning the Attorney The Republic of Indonesia is made up of the Attorney General's Office, the High Prosecutor's Office, and the District Attorney's Office. Where the highest power in the Prosecutor's Office is in the Attorney General's Office, namely the Attorney General himself, while a prosecutor is appointed and dismissed by the Attorney General, where the requirements to be appointed as a prosecutor are regulated in Act No. 16 of 2004 Article 9. In carrying out his duties and function, prosecutors act and on behalf of the state and are accountable according to hierarchical channels. Before taking office, the prosecutor is obliged to take an oath or promise according to his religion before the Attorney General. The function of the prosecutor is one of the links in the law enforcement process in overcoming crimes or criminal acts that occur in society, where this function cannot be separated and separated from the process of investigation, investigation, prosecution, trial and execution. ${ }^{5}$

Law enforcement in Indonesia, especially in corruption is a top priority for law enforcers, especially the Prosecutor's Office, the Police and the Corruption Eradication Commission (KPK) in uncovering and eradicating corruption that occurs in Indonesia. Disclosure of corruption cases carried out by law enforcers is very dependent on the investigation stage by maximizing the efforts of law enforcers in dismantling corruption cases with the facilities and infrastructure as well as the authority they have under the laws and regulations. Although the Prosecutor's Office and the Police have the same authority as the KPK in terms of conducting investigations into alleged criminal acts of corruption, the KPK has other powers that the Prosecutor's Office and the Police do not. The other authority is in carrying out investigative duties, ${ }^{6}$

The KPK has the authority to conduct wiretapping and record conversations. This authority is used by the KPK as a way to open and uncover corruption cases. The majority of cases at the KPK are cases of bribery or gratification carried out by state

\footnotetext{
${ }^{4}$ Abdul Haris, Umar Ma'ruf, and Sri Kusriyah, Role And Function Of Attorney In Order To Optimize The Prevention Of Corruption Through Establishment of TP4P/D (Case Studies In State Attorney of Grobogan), Jurnal Daulat Hukum Volume 2 Issue 4, December 2019, url: http://jurnal.unissula.ac.id/index.php/RH/article/view/8287/3863

${ }^{5}$ Sudhono Iswahyudi, 2003, Keterkaiatan Komisi Pemberantasan Korupsi dengan Kejaksaan dalam penanganan Tindak Pidana Korupsi, Papers of the Junior Attorney General for Special Crimes, p.112. ${ }^{6}$ Tim Redaksi Fokusindo Mandiri, 2013, Undang-Undang Pemberantasan Tindak Pidana Korupsi, Bandung , Fokusindo Mandiri, p. 66
} 
officials, in which case the KPK uses wiretapping and recording techniques. The Corruption Eradication Commission (KPK) is also given the authority to carry out investigations, namely to carry out confiscations without permission from the Head of the District Court, based on the provisions of Article 47 paragraph (1) of Act No. 30 of 2002. These two things are not owned by the Prosecutor and the Police. Although the Prosecutor's Office and the Police do not have this authority, it does not dampen the maximum efforts made by the Attorney General's Office and the Police. ${ }^{7}$

As for prevention of criminal acts of corruption cannot be separated from the efforts of law enforcement officials in carrying out law enforcement efforts in the field of corruption. According to Article 39 of Act No. 31 of 1999 concerning the Eradication of Criminal Acts of Corruption, it is stated that "the attorney general coordinates and controls the investigation, investigation, and prosecution of criminal acts of corruption". This article explains that the Attorney General has the right and power to carry out investigations, investigations, and prosecutions and carry out executions of judges' decisions in cases of criminal acts of corruption. This is the same as Article 30 paragraph (1) of Act No. 16 of 2004 concerning the Prosecutor's Office of the Republic of Indonesia in lieu of Act No. 5 of 1991 concerning the Prosecutor's Office of the Republic of Indonesia.

Act No. 16 of 2004 has strengthened the legal basis for the authority of the prosecutor as an investigator and public prosecutor for corruption. Placing the role of investigation and prosecution "one roof" is not in accordance with the contents of the Criminal Procedure Code. ${ }^{8}$ So it is as if the special nature of the Law on the Eradication of Criminal Acts of Corruption has given rise to dualism and can cause side effects of abuse of power from the prosecutor's office. ${ }^{9}$

As is known, one side of the function of the Prosecutor as a state apparatus in the process of law enforcement and justice is to always act based on the law and heed religious norms, decency, and decency and must explore the values of humanity, law and justice that live in society. society as an effort to create a peaceful and orderly community condition, through its general functions, namely as a Public Prosecutor and executor of court decisions, in addition to being an investigator in special criminal cases, including corruption as regulated in Act No. 1999 in conjunction with Act No. 20 of 2001 concerning the Eradication of Corruption and its amendments in conjunction with Act No. 30 of 2002 concerning the Establishment of the Corruption Eradication Commission, as well as State Attorney.

\section{Research Method}

\footnotetext{
${ }^{7}$ Endy Dasaatmaja, Investigating Prosecutor Policies Related To Completion Deadline Of Financial Losses Calculation Of The Corruption Case By Internal Government Auditor (APIP) Case Study In State Attorney of Grobogan, Jurnal Daulat Hukum Volume 2 Issue 2, June 2019, url: http://jurnal.unissula.ac.id/index.php/RH/article/view/5427/3348

${ }^{8}$ Septian Nanang Pangestu and Lathifah Hanim, The Role of Prosecution Related to Prosecutor's Demand in Enforcing the Criminal Action of Narcotics, Jurnal Daulat Hukum Volume 4 Issue 1, March 2021, url:http://jurnal.unissula.ac.id/index.php/RH/article/view/13884/5383

9 Ibid
} 
This study uses a normative juridical approach. The research specifications are descriptive analytical. The types of data used in this study are secondary data, namely: covering primary legal materials, secondary legal materials and tertiary legal materials. The data collection technique in this research is the literature study method. After the data from the field was collected using the data collection method described above, it was analyzed using qualitative descriptive analysis. The data analysis used in this research is qualitative data analysis.

\section{Result and Discussion}

Corruption comes from the Latin: corruption from the verb corrumpere which means rotten, damaged, destabilized, twisted, bribed. According to Transparency International, it is the behavior of public officials, whether politicians or politicians or civil servants, who unfairly and illegally enrich themselves or enrich those close to them, by abusing the public power entrusted to them. ${ }^{10}$ Whereas in the Big Indonesian Dictionary, corruption literally means: bad, damaged, likes to use goods (money) entrusted to him, can be bribed (through his power for personal gain). As for the meaning of the terminology, corruption is misappropriation or embezzlement (state or company money) for personal or other people's interests. ${ }^{11}$

The problem of eradicating corruption in Indonesia is not only a matter of law and law enforcement alone, but also a social and psychological problem which is very serious and as serious as a legal problem, so it must be addressed simultaneously. Corruption is also a social problem because corruption results in the absence of a welfare government and is a social psychological problem because corruption is a social disease that is difficult to cure. ${ }^{12}$

There are agencies that regulate law enforcement dealing with corruption, such as: Prosecutors, who have the authority to conduct investigations into criminal acts in accordance with the law on which they are based. ${ }^{13}$ In particular, corruption crimes that occur in various world gaps, including in Indonesia, so that the prosecutor's office is needed to be able to handle corruption in accordance with the laws and regulations that apply in Indonesia. So the main purpose of the investigation is to make light of the crime that occurred in order to find the suspect.

In the enactment of Act No. 16 of 2004 concerning the Prosecutor's Office, Article 30 paragraph (1) letter d states: The duties and authorities of the Prosecutor are "to conduct investigations into certain criminal acts based on the law". ${ }^{14}$ In the

\footnotetext{
${ }^{10}$ Muhammad Shoim, 2009, Pengaruh Pelayanan Publik Terhadap Tingkat Korupsi pada Lembaga Peradilan di Kota Semarang, Laporan Penelitian Individual, Pusat Penelitian IAIN Walisongo Semarang, p.14.

${ }^{11}$ Ministry of Education and Culture RI, Kamus Besar Bahasa Indonesia, Balai Pustaka, Jakarta, 1995, p. 527

${ }^{12}$ Ermansjah Djaja, 2010, Meredesain Pengadilan Tindak Pidana Korupsi, Penerbit Sinar Grafika, p.28

${ }^{13}$ IGM Nurdjana, 2010, Sistem Hukum Pidana Dan Bahaya Laten Korupsi, ed. 1, Pustaka Pelajar, Yogyakarta, p. 4

${ }^{14}$ Anonim, 2010, Kompilasi Perundangan tentang KPK, Polisi dan Jaksa, ed. 1, Pustaka Yustisia, Jakarta, p.119
} 
explanation it is stated that what is meant by certain criminal acts based on the law is as regulated in Act No. 26 of 2000 concerning Human Rights Courts and Act No. 31 of 1999 concerning Eradication of Criminal Acts of Corruption as amended by Act No. 20 of 2001, in conjunction with Act No. 30 of 2002 concerning the Corruption Eradication Commission. ${ }^{15}$

In Article 13 of Act No. 16 of 2004 concerning the Prosecutor's Office of the Republic of Indonesia, it can be read that the provision reads: "The Public Prosecutor is the Prosecutor who is authorized by this Law to carry out prosecutions and implement judges' decisions". Seeing the formulation of the definition of the public prosecutor put forward, the scope of authority and function of the prosecutor as a public prosecutor is very much reduced when compared to what is stipulated in the HIR. His main duties and powers are only limited:

- Carry out prosecutions;

- Carry out the judge's determination;

- Implement the judge's decision that has obtained permanent legal force. ${ }^{16}$

This is due to the principles of the Criminal Procedure Code, which establishes the basis for functional differentiation between law enforcers. The public prosecutor's authority has been based on HIR and Act No. 15 of 1961 jo. Act No. 5 of 1991 has been partially withdrawn, then the authority that was withdrawn from its function was transferred completely to the National Police, which functionally differentiation has been specialized as "Sole Investigator". Thus, the prosecutor's authority as a public prosecutor is removed to carry out:

- Investigation;

- Investigation and investigative examination;

- Search;

- Foreclosure; and

- Likewise, the date of his authority as a further investigating officer. Even KUHAP itself does not recognize the terms and techniques of further investigation.

The benefits of specialization in law enforcement functions among the ranks of law enforcement officers, especially the strict separation of functions and authorities between the Police and the Prosecutor's Office. However, the focus is more on the problems of (1) clarifying functions that aim to eliminate confusion and overlapping investigation functions and powers, (2) functional specialization can fulfill the principles of justice or law enforcement which are simpler, faster, and less expensive. ${ }^{17}$

Exceptions Based on Article 284 paragraph (2) of the Criminal Procedure Code. The Criminal Procedure Code has relinquished the investigative authority from the prosecutor's office, and has been fully assigned to the police However, even so, Article 284 paragraph (2) as an article "transitional provisions" from the HIR period to the Criminal Procedure Code still leaves the investigative authority to the public prosecutor throughout the HIR period to the Criminal Procedure Code that still leaves

\footnotetext{
15 Ibid, p. 136-137

${ }^{16}$ M. Yahya Harahap, 2012, Pembahasan Permasalahan dan Penerapan KUHAP, Penyidikan dan Penuntutan, Edisi Kedua, Sinar Grafika, Jakarta, p.365-366

17 Ibid
} 
the investigative authority to the public prosecutor as long as it concerns certain criminal acts, such as economic crimes and corruption. ${ }^{18}$

Especially regarding the transitional regulation referred to in Article 284 paragraph (2), because this transitional regulation has a rather special relation to the function and authority of the prosecutor as a public prosecutor. Because the transitional regulation paragraph (2) involves prosecutors or public prosecutors as investigators in "special crimes", even prosecutors are authorized to carry out investigations. ${ }^{19}$ Article 284 paragraph (2) states: "Within two years after this law is promulgated, the provisions of this Law shall apply to all cases, with the temporary exception of the special provisions on criminal procedures as referred to in certain laws, until there is a change and or declared no longer valid". With the explanation of Article 284 paragraph (2).

- What is meant by all cases are cases that have been delegated to the court;

- What is meant by "special provisions" for criminal procedures as stipulated in certain laws" are special provisions for criminal procedures as referred to in:

- Law on the investigation, prosecution of economic crimes (Emergency Act No. 7 of 1955);

- Law on the eradication of criminal acts of corruption (Act No. 3 of 1971), with a note that all special provisions on criminal procedures as mentioned in certain laws will be reviewed, amended or revoked in the shortest possible time. ${ }^{20}$

The prosecutor as a public prosecutor in a criminal case must clearly know all the work that must be carried out by the investigator from the beginning to the end, all of which must be carried out by law. The prosecutor will be responsible for all treatment of the accused, starting with the suspect being investigated, then the case is examined, then detained, and finally whether the demands made by the prosecutor are legal and true or not according to law, so that the community's sense of justice is truly fulfilled. ${ }^{21}$

The problem that sometimes arises is the overlapping authority in handling corruption cases between the Prosecutor's Office, the Police and the KPK. Arrangements for investigations in corruption crimes between the prosecutor's office and the corruption eradication commission, among others, for the prosecutor's office, are contained in the Criminal Procedure Code in Article 284 paragraph (2), Article 17 Government Regulation No. 27 of 1983, and Act No. 16/2004. Regarding the Prosecutor's Office of the Republic of Indonesia, while the Corruption Eradication Commission in conducting investigations of criminal acts of corruption, the arrangements are contained in the Criminal Procedure Code and Law of the Republic of Indonesia Number 19 of 2019 concerning the Second Amendment to Act No. 30 of 2002 concerning the Eradication Commission. Corruption Crimes. Second, regarding the criteria for a corruption case that can be delegated between the prosecutor's office to the corruption eradication commission or vice versa, the researcher concludes that

\footnotetext{
18 Ibid, p. 367

19 Ibid, p. 368

20 Ibid

21Evi Hartanti, 2006, Tindak Pidana Korupsi, Sinar Grafika, Jakarta, p. 32
} 
for the prosecutor's office there are no specific criteria that regulate the transfer of files for a corruption case to the Corruption Eradication Commission because the prosecutor himself has the right to conduct an investigation., investigations, and prosecutions for cases of criminal acts of corruption, while the Corruption Eradication Commission has special criteria in taking action on a case as described in Article 10, Article 10A, Article 11 of Law of the Republic of Indonesia Number 19 of 2019 concerning the Second Amendment to the Act No. 30 of 2002 concerning the Corruption Eradication Commission.

\section{Closing}

The duties and functions of the prosecutor as an investigator of corruption in accordance with the provisions of Article 284 paragraph (2) of the Criminal Procedure Code, the Prosecutor is still authorized to carry out investigations of special crimes in this case corruption. Eradication of corruption is to rely on the consistent treatment of Law on the eradication of corruption. 20 of 2001 concerning amendments to Act No. 31 of 1999 concerning the eradication of corruption. The prosecutor as an investigator concurrently serves as a public prosecutor in handling corruption crimes. Exceptions Based on Article 284 paragraph (2) of the Criminal Procedure Code. The Criminal Procedure Code has relinquished the investigative authority from the prosecutor's office, and has been fully assigned to the police But even so, Article 284 paragraph (2) as an article "transitional provisions" from the HIR period to the Criminal Procedure Code still leaves the investigative authority to the public prosecutor throughout the HIR period to the Criminal Procedure Code still leaves the investigative authority to the public prosecutor as long as it concerns certain criminal acts, such as economic crimes and corruption. For this reason, suggestions can be submitted in the role of the Prosecutor as an investigator as well as a public prosecutor in corruption crimes, it is necessary to improve coordination between fellow law enforcers.

\section{References}

Journal:

[1] Abdul Haris, Umar Ma'ruf, and Sri Kusriyah, Role And Function Of Attorney In Order To Optimize The Prevention Of Corruption Through Establishment Of TP4P/D (Case Studies In State Attorney Of Grobogan), Jurnal Daulat Hukum Volume 2 Issue 4, December 2019, url: http://jurnal.unissula.ac.id/index.php/RH/article/view/8287/3863

[2] Endy Dasaatmaja, Investigating Prosecutor Policies Related To Completion Deadline Of Financial Losses Calculation Of The Corruption Case By Internal Government Auditor (APIP) Case Study In State Attorney Of Grobogan, Jurnal Daulat Hukum Volume 2 Issue 2, June 2019, url: http://jurnal.unissula.ac.id/index.php/RH/article/view/5427/3348

[3] Muhamad Riyadi Putra and Gunarto, Analysis Of Handling Practices On Corruption Crime By Police (Case Study In Special Criminal Investigation Police Directorate Of Central Java), Jurnal Daulat Hukum Volume 2 Issue 2, June 2019, url: http://jurnal.unissula.ac.id/index.php/RH/article/view/5425/3346 
[4] Septian Nanang Pangestu and Lathifah Hanim, The Role of Prosecution Related to Prosecutor's Demand in Enforcing the Criminal Action of Narcotics, Jurnal Daulat Hukum Volume 4 Issue 1, March 2021, url:http://jurnal.unissula.ac.id/index.php/RH/article/view/13884/5383

Books:

[1] Anonim, 2010, Kompilasi Perundangan tentang KPK, Polisi dan Jaksa, Ed. 1, Pustaka Yustisia, Jakarta

[2] Ministry of Education and Culture RI, Kamus Besar Bahasa Indonesia, Balai Pustaka, Jakarta, 1995

[3] Ermansjah Djaja, 2010, Meredesain Pengadilan Tindak Pidana Korupsi, Penerbit Sinar Grafika

[4] Evi Hartanti, 2005, Tindak Pidana Korupsi, Sinar Grafika, Jakarta

[5] IGM Nurdjana, 2010, Sistem Hukum Pidana Dan Bahaya Laten Korupsi, Ed. 1, Pustaka Pelajar, Yogyakarta

[6] Muhammad Shoim, 2009, Pengaruh Pelayanan Publik Terhadap Tingkat Korupsi pada Lembaga Peradilan di Kota Semarang, Laporan Penelitian Individual, Pusat Penelitian IAIN Walisongo Semarang

[7] M.Yahya Harahap, 2012, Pembahasan Permasalahan dan Penerapan KUHAP, Penyidikan dan Penuntutan, Edisi Kedua, Sinar Grafika, Jakarta

[8] Saipuddin Zahri, 2016, Problema Penyidikan Tindak Pidana Korupsi, Palembang: Tunas Gemilang Press

[9] Soemitro, 1998, Metodologi Penelitian Hukum dan Jurimetri, Jakarta, Ghalia Indonesia

[10] Sudhono Iswahyudi, 2003, Keterkaiatan Komisi Pemberantasan Korupsi dengan Kejaksaan dalam penanganan Tindak Pidana Korupsi, Makalah Jaksa Agung Muda Tindak Pidana Khusus

[11] Tim Redaksi Fokusindo Mandiri, 2013, Undang-Undang Pemberantasan Tindak Pidana Korupsi, Bandung, Fokusindo Mandiri 